\title{
Identification of Astyanax altiparanae (Teleostei, Characidae) in the Iguaçu River, Brazil, based on mitochondrial DNA and RAPD markers
}

\author{
Sônia M.A.P. Prioli ${ }^{1,2}$, Alberto J. Prioli ${ }^{1,2}$, Horácio F. Júlio Jr. ${ }^{1,2}$, Carla S. Pavanelli ${ }^{2}$, \\ Alessandra V. de Oliveira ${ }^{2,3}$, Helaine Carrer $^{4}$, Dirce M. Carraro ${ }^{5}$ and Laudenir M. Prioli ${ }^{2,3}$ \\ ${ }^{I}$ Departamento de Biologia Celular e Genética, Universidade Estadual de Maringá, Maringá, PR, Brasil. \\ ${ }^{2}$ Núcleo de Pesquisas em Limnologia Ictiologia e Aqüicultura (NUPELIA), \\ Universidade Estadual de Maringá, Maringá, PR, Brasil. \\ ${ }^{3}$ Departamento de Biologia, Universidade Estadual de Maringá, Maringá, PR, Brasil. \\ ${ }^{4}$ Departamento de Ciências Biológicas, Escola Superior de Agricultura Luiz de Queiroz, \\ Universidade de São Paulo, Piracicaba, SP, Brasil. \\ ${ }^{5}$ Ludwig Institute for Cancer Research, São Paulo, SP, Brasil.
}

\begin{abstract}
Astyanax fishes are among the most important food-web components of South America rivers. In the Iguaçu River basin, the Astyanax genus is represented mainly by endemic species. For millions of years, that hydrographic basin has been geographically isolated from the Paraná River basin by the Iguaçu Falls. Recently, a species from the Upper Paraná River basin identified as Astyanax bimaculatus was revised and described as a new species named Astyanax altiparanae Garutti \& Britski, 2000. Fauna endemism and geographic isolation triggered interest in investigations to evaluate the identification and genetic relatedness among two $A$. altiparanae populations from the Upper Paraná River basin and the population identified as $A$. bimaculatus in the Iguaçu River, upstream from the Iguaçu Falls. Mitochondrial DNA sequences and RAPD markers revealed high genetic diversity within each population, as well as low genetic distance, high gene flow, and high mitochondrial DNA similarity among all three populations. In conjunction with morphological similarities, these results demonstrated that the population presently known as Astyanax bimaculatus in the Iguaçu River should actually be stated as Astyanax altiparanae. Furthermore, it could be inferred that the $A$. altiparanae population is not endemic and most likely it was recently introduced in the Iguaçu River basin, maintaining the ancestral genetic identity.
\end{abstract}

Key words: Astyanax, fish, D-loop, control region, mitochondrial DNA, RAPD.

Received: July 31, 2002; accepted: November 4, 2002.

\section{Introduction}

Species of the genus Astyanax Baird \& Girard, 1854 are among the most important components of the food-web in South America rivers, with a significant participation in the diet of big fishes. There are about one hundred nominal species and subspecies described in this genus, but many aspects of their taxonomy are still unknown. In the Iguaçu River basin, Paraná State, Brazil, Astyanax is represented mainly by seven or eight endemic species. The Iguaçu ichthyofauna has a peculiar evolutionary history, with a high rate of endemism in a cataract-ridden fluvial environment. Approximately $80 \%$ of the species are exclusive to this hydrographic basin and non-existent elsewhere on the planet (Agostinho and Gomes, 1997). Among the many

Send correspondence to A.J.P. E-mail: ajprioli@ nupelia.uem.br. falls in the river's 1,060 km course, the Iguaçu Falls are the most outstanding. They are located about $22 \mathrm{~km}$ from the mouth of the Iguaçu River where it discharges into the Paraná River. Dated from the Oligocene, about 22 million years ago, and dropping $72 \mathrm{~m}$, the Iguaçu Falls isolate the ichthyofauna of the Iguaçu River basin from that of the Paraná River basin (Haseman, 1911; Sampaio, 1988).

All Astyanax species existing in the Paraná River basin are absent in the hidrographic basin of Iguaçu, with exception of a fish population popularly known as tambiu and lambari-de-rabo-amarelo. In the Paraná River basin, this fish population had been identified as Astyanax bimaculatus, but recently it was revised and described by Garutti and Britski (2000) as a new species named Astyanax altiparanae Garutti \& Britski, 2000. It is indicated that only the species from Surinam, apparently the holotype of this species, should a priori be called $A$. 
bimaculatus. The geographical isolation of the Iguaçu River basin and the special characteristics of its ichthyofauna endemism instigated an investigation as to whether the tambiú population from the Iguaçu River, above the falls, referred to as A. bimaculatus (Garavello et al., 1997) belongs to the $A$. altiparanae species found in tributaries of the Upper Paraná River basin. Current work in systematics of fishes has counted on the foundation and starting point provided by the remarkable success achieved by morphological studies. In the last decade, new suites of characters provided by molecular approaches have helped to invigorate studies of fish systematics. Interspecific and intraspecific genetic variation analyzed by mitochondrial DNA (mtDNA) sequences and Random Amplified Polymorphic DNA (RAPD) are among the molecular tools most widely used in these studies.

The mitochondrial genome co-evolves, with a certain degree of independence, at its own faster rate together with the host organism. Analyses of nucleotide variations in mtDNA sequences have been extremely helpful in polymorphism studies and phylogenetic analysis of natural fish populations (Kocher and White 1989; Stepien and Kocher 1997; Sivasundar et al., 2001). The mitochondrial control region is the main noncoding region and the most variable of metazoan mtDNA, including fishes. It is characterized by the displacement loop (D-loop), a DNA segment that is complementary to the L-strand, and that displaces the $\mathrm{H}$-strand. In addition to conserved segments, the control region contains interposed sequences in the 5' and 3' domains, which have high levels of polymorphism. The rate of evolution of the control region is two to five times higher than that of the mitochondrial protein coding genes. Because mutations accumulate fastest in the control region, mainly in the 5' domain, this is the main mtDNA sequence of choice for population and phylogenetic studies among closely related species, including fish species (Meyer, 1994; Faber and Stepien, 1977; Sivasundar et al., 2001).

The RAPD technique consists of DNA analysis of fragments amplified by Polymerase Chain Reaction (PCR) with single primers of randomized sequences (Williams et al., 1990). These primers, consisting of randomized sequences, do not discriminate between coding and noncoding regions. It may be thus admitted that the RAPD technique samples the genome in a highly randomized way (Williams et al., 1990). In fishes, RAPD has been successfully used to supplement systematic and phylogenetic studies of natural populations, including species and sub-species (Stepien and Kocher 1997; Almeida et al. 2001; Oliveira et al., 2002).

In the present work, mitochondrial DNA sequences and RAPD markers were used to study the genetic relatedness between the non-endemic Astyanax population from the Iguaçu River, upstream from the Iguaçu Falls, and two A. altiparanae populations from tributaries of the Paraná River basin, attempting to study the identification and pos- sible origin of this Astyanax population existent in the Iguaçu River basin.

\section{Materials and Methods}

\section{Fish sampling and DNA extraction}

Astyanax altiparanae ${ }^{1}$ was sampled in the Keller and Pirapó tributaries of the Upper Paraná River basin, near Maringá, Northern Paraná State, Brazil. The Pirapó belongs to the Paranapanema River sub-basin and the Keller belongs to the Ivaí River sub-basin, both in the hydrographic basin of the Upper Paraná River. In the Iguaçu River, Astyanax ${ }^{2}$ specimens of interest were collected at the Salto Caxias Hydroelectric reservoir, soon after impounding, located about $200 \mathrm{~km}$ from Iguaçu Falls. The related species, Astyanax sp B ${ }^{2}$ was chosen as an outgroup for genetic analyses. This species is endemic to the Iguaçu River basin, and it was sampled at the Salto Caxias Hydroelectric reservoir. Specimens were captured by gill nets and immediately frozen in liquid nitrogen. Species identification was undertaken on the basis of morphological characteristics, in agreement with Sampaio (1988), Garavello et al. (1997), and Garutti and Britski (2000). Samples of muscle tissues were taken for DNA extraction. Sampled fishes were numbered, preserved in $10 \%$ formaldehyde for a month, and then they were transferred to $70{ }^{\circ} \mathrm{GL}$ ethanol.

Extraction of total DNA was performed according to Whitmore et al. (1992), with a few modifications. Approximately $1 \mathrm{~g}$ of muscle tissue was macerated in the presence of liquid nitrogen. Extraction buffer $(500 \mu \mathrm{L})$ was added, consisting of $100 \mathrm{mM}$ Tris- $\mathrm{HCl} \mathrm{pH} 8.0,10 \mathrm{mM}$ EDTA (ethylenediaminetetraacetic acid), $0.1 \%$ SDS (sodium dodecyl sulphate), $50 \mathrm{mM}$ DTT (dithiothreitol), and $0.5 \mathrm{mg} / \mathrm{mL}$ proteinase $\mathrm{K}$. After shaking for one hour at $60 \mathrm{Srpm}$, at $42{ }^{\circ} \mathrm{C}$, DNA was extracted with an equal volume of phenol, and then with chloroform/isoamylic alcohol $(24: 1 \mathrm{v}: \mathrm{v})$. DNA was then precipitated by addition of two volumes of cold ethanol $100 \%$, followed by incubation at $-20{ }^{\circ} \mathrm{C}$ for $12-24 \mathrm{~h}$. After centrifugation at $10,000 \mathrm{x} \mathrm{g}$ for $10 \mathrm{~min}$, the precipitate was washed with ethanol $80 \%$ and resuspended in diluted TE buffer $(0.1 \mathrm{mM}$ Tris- $\mathrm{HCl} \mathrm{pH} 8.0$, $0.01 \mathrm{mM}$ EDTA), containing RNAase $(20 \mu \mathrm{g} / \mathrm{mL})$. The DNA suspension was stored at $-21{ }^{\circ} \mathrm{C}$. Aliquots of each sample were used for visual estimation of DNA quantity by

${ }^{1}$ Voucher Specimens from Upper Paraná River basin: Astyanax altiparanae - NUP2700 (20 ex.), Keller River, tributary to Ivaí River, Marialva, Paraná State (PR), Brazil, collected by Prioli AJ \& Júlio Jr HF, October, 2000, and NUP2701 (12 ex.), Cidade Canção fisher-ground, Águas Maringá stream, affluent to Pirapó River, Maringá, PR Brazil, collected by Furuya WM, Prioli JA \& Prioli SMAP, October $10^{\text {th }}, 2000$.

${ }^{2}$ Voucher Specimens from Iguaçu River basin: Astyanax altiparanae - NUP1623 (100ex.), and Astyanax sp B - NUP2457 (44 ex.), Iguaçu River, Caxias Reservoir, Capitão Leônidas Marques and Nova Prata do Iguaçu townships, $25^{\circ} 30^{\prime} \mathrm{S} / 53^{\circ} 25^{\prime} \mathrm{W}$, PR, Brazil, collected by Nupelia staff, January $25^{\text {th }}, 1999$. 
comparison with known quantities of phage $\lambda$ DNA in agarose gel $(0.8 \%)$, and stained with ethydium bromide $(20 \mu \mathrm{g} / 100 \mathrm{~mL})$.

\section{PCR and sequencing of mitochondrial DNA}

A mtDNA fragment (approx. $800 \mathrm{bp}$ ) was amplified by PCR from DNA samples of six to seven fishes of each Astyanax population. For each fish specimen, the mtDNA fragment was amplified in three independent PCR reactions and they were then sequenced and analyzed, as replicates. The primers H16498 5'-CACCTGAAGTAGGAACCA GATG-3' (Meyer et al., 1990), and L15774M 5'-ACATGAATTGGAGGTATACCAGT-3', which was modified from the L15774 primer described by Irwin et al. (1991), were used for PCR amplifications. PCR reaction mix consisted of Tris- $\mathrm{KCl}(20 \mathrm{mM}$ Tris- $\mathrm{HCl} \mathrm{pH} 8.4$ plus $50 \mathrm{mM} \mathrm{KCl}), 1.5 \mathrm{mM} \mathrm{MgCl} 2,2.5 \mu \mathrm{M}$ of each primer, $0.1 \mathrm{mM}$ of each dNTP, $2.5 \mathrm{U}$ Taq-polymerase, $15 \mathrm{ng}$ total DNA and water to a total volume of $25 \mu \mathrm{L}$. PCR amplification was performed in a first cycle of $94^{\circ} \mathrm{C}$ for $4 \mathrm{~min}, 50^{\circ} \mathrm{C}$ for $30 \mathrm{~s}$, and $72{ }^{\circ} \mathrm{C}$ for $2 \mathrm{~min}$, followed by 40 cycles of $94^{\circ} \mathrm{C}$ for $15 \mathrm{~s}, 56^{\circ} \mathrm{C}$ for $30 \mathrm{~s}, 72^{\circ} \mathrm{C}$ for $2 \mathrm{~min}$, and a final extension step of $72{ }^{\circ} \mathrm{C}$ for $10 \mathrm{~min}$. After amplification, an aliquot was taken from each PCR reaction mix, and the amplified DNA fragment was quantified in agarose gel by comparison with known quantities of phage $\lambda$ DNA.

The final DNA product obtained from each PCR reaction was used directly as template for sequencing on an ABI-3100 (Perkin Elmer, Norwalk, CT, USA) automated sequencer. Sequencing was performed with BigDye ${ }^{\mathrm{TM}}$ Terminator Cycle Sequencing v. 2.0 kit (Perkin Elmer Biosystems), according to the manufacturers instructions. Approximately $50 \mathrm{ng}$ of template DNA and 20 pmol of either L15774M or H16498 primer were added to each sequencing reaction. Immediately after heating the reaction mix at $94{ }^{\circ} \mathrm{C}$ for $4 \mathrm{~min}$, amplifications were performed in 35 cycles of $30 \mathrm{~s}$ at $94{ }^{\circ} \mathrm{C}, 30 \mathrm{~s}$ at $55^{\circ} \mathrm{C}$, and $1 \mathrm{~min} 30 \mathrm{~s}$ at $60{ }^{\circ} \mathrm{C}$, followed by $5 \mathrm{~min}$ at $60^{\circ} \mathrm{C}$. Sequencing data, under chromatogram format, were directly collected by the Sequencing Analysis program (Perkin Elmer) and submitted to quality check, assembly and alignment on the Vector NTI Suite version 6.0 software (Informax, Inc.). The nucleotide sequence of each specimen was confirmed in at least three replicates, consisting of three independent PCR reactions.

A 569-nucleotide portion of the 5' side of the mitochondrial control region of 24 individuals was used in genetic relatedness analyses. In addition, a corresponding mtDNA segment of the control region of the closely related species Astyanax sp B was sequenced and included as an outgroup in the analysis. Genetic analyses were performed with MEGA version 2.1 (Kumar et al., 2001). Genetic distances of Tamura and Nei (1993) with gamma distribution were calculated and clustered into a distance neigh- bor-joining tree (Saitou and Nei, 1987). Bootstrap analyses were based on 1000 replications. The Gamma coefficient was estimated by using PAUP* version 4.0 (Swofford, 2002).

\section{RAPD electrophoresis profile analysis}

Eighteen fishes from the Iguaçu River, and eighteen from both tributaries of the Upper Paraná River basin were evaluated by RAPD markers. Initial tests of PCR primers were undertaken by using Astyanax DNA in amplifications with two sets of 20 decamers of Kits X and W from Operon Technologies (Alameda, CA, USA). Primers amplifying the highest number of fragments and producing accurate bands were chosen for RAPD analysis. PCR reaction mixture consisted of buffer Tris- $\mathrm{KCl}(20 \mathrm{mM}$ Tris- $\mathrm{HCl} \mathrm{pH} 8.4$ and $50 \mathrm{mM} \mathrm{KCl}$ ), $2 \mathrm{mM} \mathrm{MgCl}, 0.46 \mu \mathrm{M}$ primer, $0.2 \mathrm{mM}$ dNTP, 1U/Reaction of Taq-polymerase (Gibco BRL), 10 ng DNA, and sterile deionized water to a total volume of $13 \mu \mathrm{L}$. The reaction mixture was heated at $92{ }^{\circ} \mathrm{C}$ for $4 \mathrm{~min}$, followed by 40 cycles of $1 \mathrm{~min}$ at $92^{\circ} \mathrm{C}, 1 \mathrm{~min} 30 \mathrm{~s}$ at $40^{\circ} \mathrm{C}$ and $2 \mathrm{~min}$ at $72^{\circ} \mathrm{C}$. Immediately after the last amplification cycle, the reaction mixture was maintained at $72{ }^{\circ} \mathrm{C}$ for 5 min and then cooled at $4{ }^{\circ} \mathrm{C}$ for $20 \mathrm{~min}$. PCR amplified DNA fragments were separated by electrophoresis in agarose gel $(1.4 \%)$, stained with ethydium bromide $(20 \mu \mathrm{g} / 100 \mathrm{~mL})$, at $3 \mathrm{~V} \cdot \mathrm{cm}^{-1}$ for 5-6 h. A sample was included as a negative control in each experiment, consisting of the PCR reaction mixture without template DNA. In addition, 1 to 3 samples of PCR products, containing Astyanax DNA fragments previously amplified and analyzed with the same primer, were included in each agarose gel. The electrophoretic profile was visualized under UV radiation and photographed with Kodak EDAS-290. Sizes of DNA fragments were estimated by comparison with the standard Ladder $100 \mathrm{pb}$ (Gibco BRL).

Unbiased genetic distances based on RAPD markers were estimated according to Nei (1978), with Lynch and Milligan's (1994) correction, using the software Rapddist (Black and Antolin, 1997). The Shannon gene diversity indexes were calculated with the software Popgen 1.31 (Yeh et al., 1999). The Shannon diversity index was used to quantify levels of genetic diversity in isolated populations and for the partition of components within and between populations. Shannon's diversity index has been useful for RAPD data analysis due to its relative non-sensitivity to bias, which could be introduced in data because of the impossibility of detecting heterozygous individuals. Fixation index $F_{\text {st }}$, and gene flow, equivalent to the number of migrants per generation $(\mathrm{Nm})$, were estimated according to Lynch and Milligan (1994), with the computer program RAPDFST (Black, 1997). The arithmetic complement of the coefficient of similarity among individuals, according to Nei and Li (1979) was estimated by using RAPDPLOT 3.0 (Black, 1997). Clustering was performed by the neigh- 
bor-joining method (Saitou and Nei, 1987), with MEGA 2.1 (Kumar et al., 2001).

\section{Results}

\section{Mitochondrial DNA}

A mtDNA fragment of approximately $800 \mathrm{bp}$ was amplified by PCR from all Astyanax specimens. This mtDNA fragment consisted of approximately $90 \mathrm{bp}$ of the 3 ' end of the mitochondrial cytochrome b gene (GenBank Accession Numbers AF531481 to AF531504), immediately followed by the complete nucleotide sequences of tRNA $^{\text {Thr }}$ and tRNA ${ }^{\text {Pro }}$ genes (GenBank Accession Numbers AF531874 to AF531897) and by a partial sequence of the 5 ' side of the control region (GenBank Accession Numbers AY125820 to AY125843). Nucleotide sequences of the control region and cytochrome $b$ were identified by similarity to GenBank accesses via BLASTN (Altschul et al., 1997) from NCBI. The tRNA genes were identified with the tRNAScan-SE program (Lowe and Eddy, 1997). Altogether, twenty mtDNA sequences, amplified from twenty specimens, were analyzed. The cytochrome $b, \mathrm{tRNA}^{\mathrm{Thr}}$, and RRNA $^{\text {Pro }}$ nucleotide sequences were identical among individuals of all three Astyanax populations, thus these genes were excluded from analyses. Nucleotide polymorphism was restricted to the amplified control region sequence, from which $569 \mathrm{bp}$ were analyzed in this work. As shown in Figure 1, multiple alignment of these Astyanax sequences revealed 27 polymorphic nucleotides, approximately $4.7 \%$, in the Keller, Pirapó, and Iguaçu populations. Altogether, a total of eleven different control-region haplotypes were identified among twenty individuals of these populations. Changes were mostly single nucleotide substitutions. On the other hand, in comparisons of these three populations with the outgroup Astyanax sp B, the percentage of polymorphic sites was increased to approximately $30 \%$. A high polymorphism level was also detected when the nucleotide sequence of the mitochondrial control region from another characid species, Oligosarcus paranensis, was tested as the outgroup, replacing Astyanax sp B (data not shown).

As shown in Table I, low genetic distances of Tamura and Nei (1993) with gamma distribution, based on control region nucleotide sequences, were estimated among the Keller, Pirapó, and Iguaçu populations, at a maximum value of 0.019 . On the other hand, high genetic distances, ranging from 3.176 to 3.527 , were calculated between these three populations and Astyanax sp B. As expected, in the neighbor-joining tree, the Keller, Pirapó, and Iguaçu specimens were combined as a single cluster, distant from the outgroup (Figure 2). Within the subtree, an intermix of individuals from the Keller, Pirapó and Iguaçu rivers clearly demonstrated the high molecular similarity among these Astyanax specimens. The distances among individuals of the three populations were in a similar magnitude observed among the individuals from the outgroup population, as represented in the tree branches (Figure 2). Low bootstrap values can be attributed to the low molecular differences among individuals within the cluster. As a contrast, this subtree was clearly separated in a high distance, with $100 \%$ bootstrap value, from the related Astyanax sp B species used as outgroup.

\section{RAPD markers}

In each Astyanax population, a total of 10 selected primers were used for DNA amplifications by PCR. Amplified DNA fragments counted for 79 polymorphic bands, seven $100 \%$ monomorphic bands and one monomorphic band at $5 \%$ probability level. RAPD electrophoresis profiles are represented in Figure 3, for one of the selected primers. Sizes of polymorphic bands ranged from approximately 0.4 to $3.0 \mathrm{~kb}$ (Table II). The number of bands per primer varied from five to ten. Polymorphic bands were taken as RAPD markers, and they were combined in a simple matrix of binary data, with registers of presence or absence of bands. The Shannon genetic diversity index within each population was $0.58( \pm 0.15)$ for Iguaçu, $0.54( \pm 0.20)$, for Keller, and $0.50( \pm 0.25)$ for Pirapó. Estimates of Nei's unbiased genetic distances ranged from 0.050 to 0.070 (Table III). As shown in Table IV, the estimated value of fixation index $F_{\mathrm{st}}$, was not significant between the Iguaçu and Keller populations, and it was significant, only at the $5 \%$ level, between the Pirapó and Keller, as well as Pirapó and Iguaçu. The migration model among the three populations was adopted to estimate gene flow $(\mathrm{Nm})$ from $F_{\text {st }}$ (Lynch and Milligan, 1994). Each population was considered sufficiently large to present negligible genetic drift. Allele frequency of migrants among the three populations was considered to be equal to the mean of the allele frequency in the entire population. Estimates of gene flow on all loci among populations varied from 2.4 to 4.0 migrants per generation (Table IV). The low RAPD divergence among populations, as derived from the neighbor-joining tree (Figure 4), indicated that the three studied Astyanax populations form a homogeneous group; therefore, a result congruent with the high genetic similarity estimated by all analyses performed for both mtDNA and RAPD markers.

\section{Discussion}

As inferred by the mitochondrial DNA sequences and RAPD markers, the genetic similarity among the three studied Astyanax populations is so high that it is not consistent with their current taxonomic identification as two different species. Genetic relatedness estimated by molecular markers indicated that the population from the Iguaçu River and the Astyanax altiparanae population from the Keller tributary of the Upper Paraná River basin are close to genetic homogeneity and they did not differentiate, not even by genetic drift. Pirapó was the most differentiated 


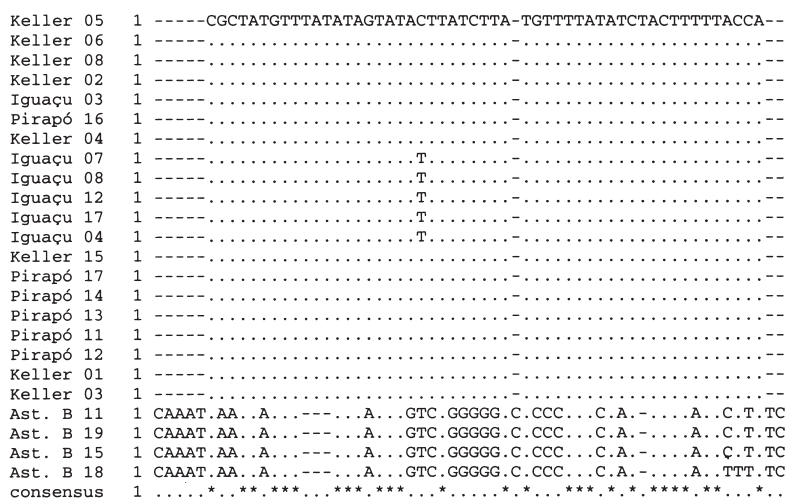

Keller 0553 CATGAACATA-GTACTACATATAAA-CATGCGTAA--AATGTAA--TTTACATAAGTGTA Keller $06 \quad 53$

Keller 08 53

$\begin{array}{lll}\text { Keller } & 02 & 53 \\ \text { Iguaçu } & 03 & 53\end{array}$

$\begin{array}{lll}\text { Iguaçu } & 03 & 53 \\ \text { Pirapó } & 16 & 53\end{array}$

Pirapó $\begin{array}{lll}16 & 53 \\ \text { Keller } & 04 & 53\end{array}$

Iguaçu $07 \quad 53$

Iguaçu 08 5

$\begin{array}{lll}\text { Iguaçu } & 12 & 53 \\ \text { Iguaçu } 17 & 53\end{array}$

Iguaçu 0453

Pirapó 1553

Pirapó 14

Pirapó 1353

Pirapó $11 \quad 53$

$\begin{array}{lll}\text { Pirapó } & 12 & 53 \\ \text { Keller } & 01 & 53\end{array}$

$\begin{array}{lll}\text { Keller } & 01 & 53 \\ \text { Keller } & 03 & 53\end{array}$

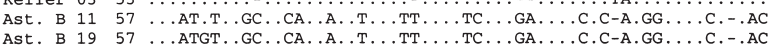

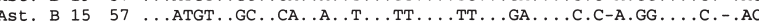

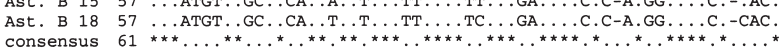

Keller 05223 GTACTGTTACATAC-ATGAAGAATTTTACATAT--GTATTAGTACATAATATGTATAATT $\begin{array}{llll}\text { Keller } & 06 & 223 \\ \text { Keller } & 08 & 223\end{array}$

$\begin{array}{llll}\text { Keller } & 08 & 223 & \\ \text { Keller } & 02 & 225\end{array}$

(

Iguaçu $03 \quad 225$

Keller $04 \quad 224$

Iguaçu $07 \quad 225$

Iguaçu $08 \quad 225$

\begin{tabular}{lll} 
Iguaçu & 12 & 225 \\
Iguaçu & 17 & 225 \\
\hline
\end{tabular}

Iguaçu $04 \quad 225$

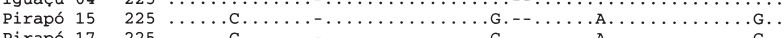

Pirapó $17 \quad 225$

Pirapó 13

Pirapó 11

Pirapó 12

Keller 01

Keller 03

$\begin{array}{lll}\text { Ast. } & \text { B } 11 \\ \text { Ast. } & \text { B } 19 \\ \text { Ast. } & \text { B } 15\end{array}$

$\begin{array}{ll}\text { Ast. } & 19 \\ \text { Ast. } & \text { B } 15 \\ \text { A } & 18\end{array}$

$\begin{array}{ll}\text { Ast. } & \text { B } 15 \\ \text { Ast. B } & 18\end{array}$

consensus

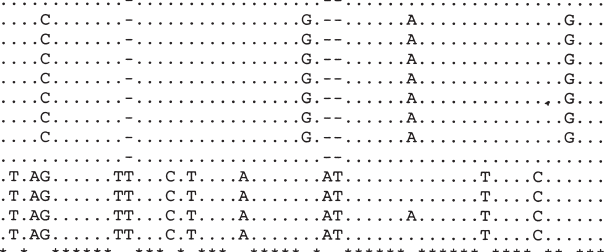

Keller 05280 TTACATAAGAACTTTATTTAAACCATTAATTTCAACTCACATGGACATGTAAAAACACAT Keller $06 \quad 280$

$\begin{array}{lll}\text { Keller } & 08 & 280 \\ \text { Kelleer } & 02 & 282\end{array}$

$\begin{array}{lll}\text { Keller } & 02 & 282 \\ \text { Iguacu } & 03 & 282\end{array}$

$\begin{array}{lll}\text { Iguaçu } & 03 & 282 \\ \text { Pirapó } 16 & 282\end{array}$

$\begin{array}{lll}\text { Pirapo } & 16 & 282 \\ \text { Keller } 04 & 281\end{array}$

Iguaçu $07 \quad 282$

Iguaçu $08 \quad 282$

Iguaçu $17 \quad 282$

Iguaçu $04 \quad 282$

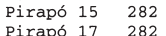

$\begin{array}{ll}\text { Pirapó } 17 & 282 \\ \text { Pirapó } 14 & 282\end{array}$

$\begin{array}{ll}\text { Pirapó } 14 & 282 \\ \text { Pirapó } 13 & 282\end{array}$

$\begin{array}{ll}\text { Pirapó } 13 & 282 \\ \text { Pirapó } 11 & 282\end{array}$

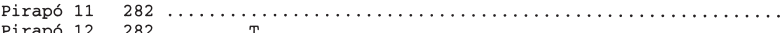

Keller 01

Keller 03

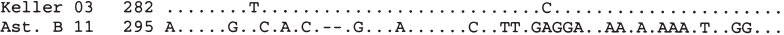

Ast. B 19295 A.... T..C.A.C. -.G..A. . . . . . .TT.GAGGA. AA.A.AAA.T. GG.

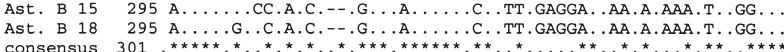

Keller 05107 AAATTAT----GCATGTATTAGTACATAATATGCATAATTATACATATATGTACTAGTAC Keller 06107

Keller 08 107.

$\begin{array}{lll}\text { Keller } & 02 & 109 \\ \text { Iguaçu } & 03 & 109\end{array}$

Pirapó 16 109

Keller 04109

Iguaçu $07 \quad 109$

Iguaçu 12109

Iguaçu $17 \quad 109$

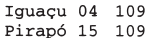

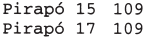

Pirapó $14 \quad 109$

Pirapó $13 \quad 109$

Pirapó 11109

Pirapó 12109

$\begin{array}{lll}\text { Keller } 01 & 109 \\ \text { Keller } 03 & 109\end{array}$

Ast. B $11 \quad 115$

$\begin{array}{lll}\text { Ast. B } 19 & 115 \\ \text { Ast. } & 15 & 115\end{array}$

$\begin{array}{lll}\text { Ast. } & 15 & 115 \\ \text { Ast. } & \text { B } 18 & 115\end{array}$

consensus 121

. T.

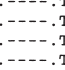

.T.
. . . .
.

\begin{tabular}{c} 
T. \\
- T. \\
\hline- T. \\
\hline T.
\end{tabular}

.

1.-

.T

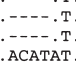

ACATAT

ACATAT

ACAT.

ACATA
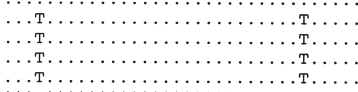

Keller 05163 ATAATATGTATAATTATACATATATGTACTAGTACATAGTATGTATAATTATACATAAAT Keller 06163

Keller 08163

$\begin{array}{lll}\text { Keller } & 02 & 16 \\ \text { Iguacu } & 03 & 16\end{array}$

$\begin{array}{lll}\text { Iguaçu } & 03 & 165 \\ \text { Pirapó } & 16 & 165\end{array}$

$\begin{array}{lll}\text { Pirapó } & 16 & 165 \\ \text { Keller } & 04 & 165\end{array}$

$\begin{array}{lll}\text { Keller } & 04 & 165 \\ \text { Iguaçu } & 07 & 165\end{array}$

Iguaçu 08 165

Iguaçu 12165

$\begin{array}{lll}\text { Iguaçu } & 17 & 165 \\ \text { Iguaçu } & 04 & 165\end{array}$

$\begin{array}{lll}\text { Iguaçu } & 04 & 165 \\ \text { Pirapó } & 15 & 16\end{array}$

Pirapó 17165

$\begin{array}{lll}\text { Pirapó } & 14 & 165 \\ \text { Pirapó } & 13 & 165\end{array}$

$\begin{array}{lll}\text { Pirapó } & 13 & 165 \\ \text { Pirapó } & 11 & 165\end{array}$

$\begin{array}{lll}\text { Pirapó } & 11 & 165 \\ \text { Pirapó } & 12 & 165\end{array}$

$\begin{array}{lll}\text { Pirapó } & 12 & 165 \\ \text { Keller } & 01 & 165\end{array}$

$\begin{array}{lll}\text { Keller } & 01 & 165 \\ \text { Keller } & 03 & 165\end{array}$

Ast. B 11 175

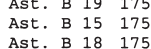

$\begin{array}{ll}\text { Ast. B } 18 & 175 \\ \text { consensus } & 181\end{array}$

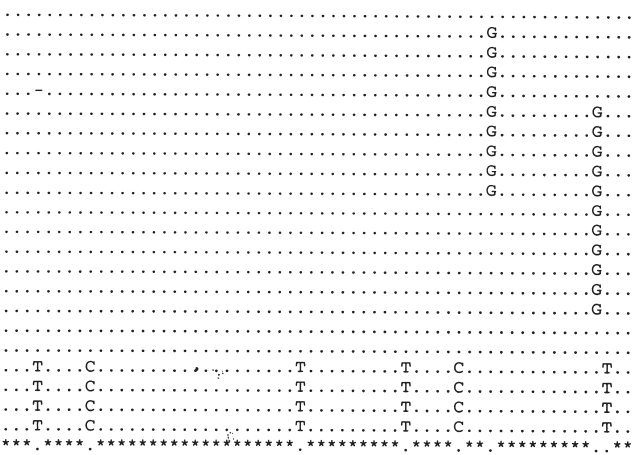

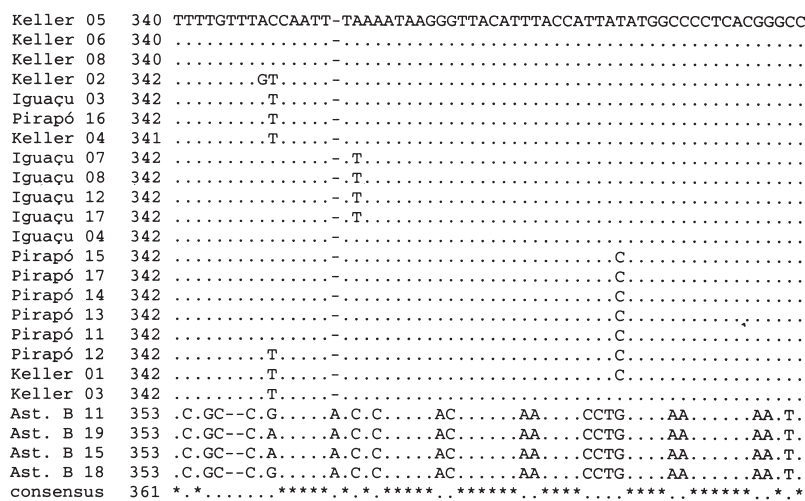

Keller 05399 T-ATTAATTAAACTTGATAACTGGAAACTC-CCCATGAACTCCATCACAAAATTTTC-TA Keller 06 399 .

Keller $02 \quad 401$

$\begin{array}{lll}\text { Iguaçu } & 03 & 401 \\ \text { Pirapó } & 16 & 401\end{array}$

$\begin{array}{lll}\text { Pirapó } 16 & 401 \\ \text { Keller } & 04 & 400\end{array}$

$\begin{array}{lll}\text { Keller } & 04 & 400 \\ \text { Iguaçu } 07 & 401\end{array}$

Iguaçu 08401

$\begin{array}{lll}\text { Iguaçu } & 12 & 40 \\ \text { Iguaçu } 17 & 401\end{array}$

Iguaçu 04401

Pirapó 15 401

Pirapó $17 \quad 401$.

Pirapó $14 \quad 401$

Pirapó $\begin{array}{ll}13 & 401 \\ \text { Pirapó } 11 & 401\end{array}$

$\begin{array}{lll}\text { Pirapó } & 11 & 401 \\ \text { Pirapó } & 12 & 401\end{array}$

Keller 01401

Keller 03401

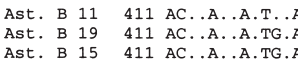

Ast. B $18 \quad 411$ AC..A.A. A.TG.

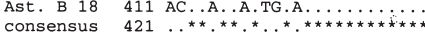

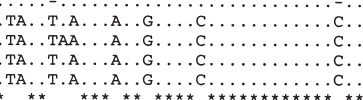

Figure 1 - Multialignment on Clustal W of nucleotide sequences from the mitochondrial control region of Astyanax altiparanae specimens from the Iguaçu River and from the Keller and Pirapó tributaries of the Upper Paraná River basin, and specimens of the closely related species Astyanax sp B from Iguaçu River. 


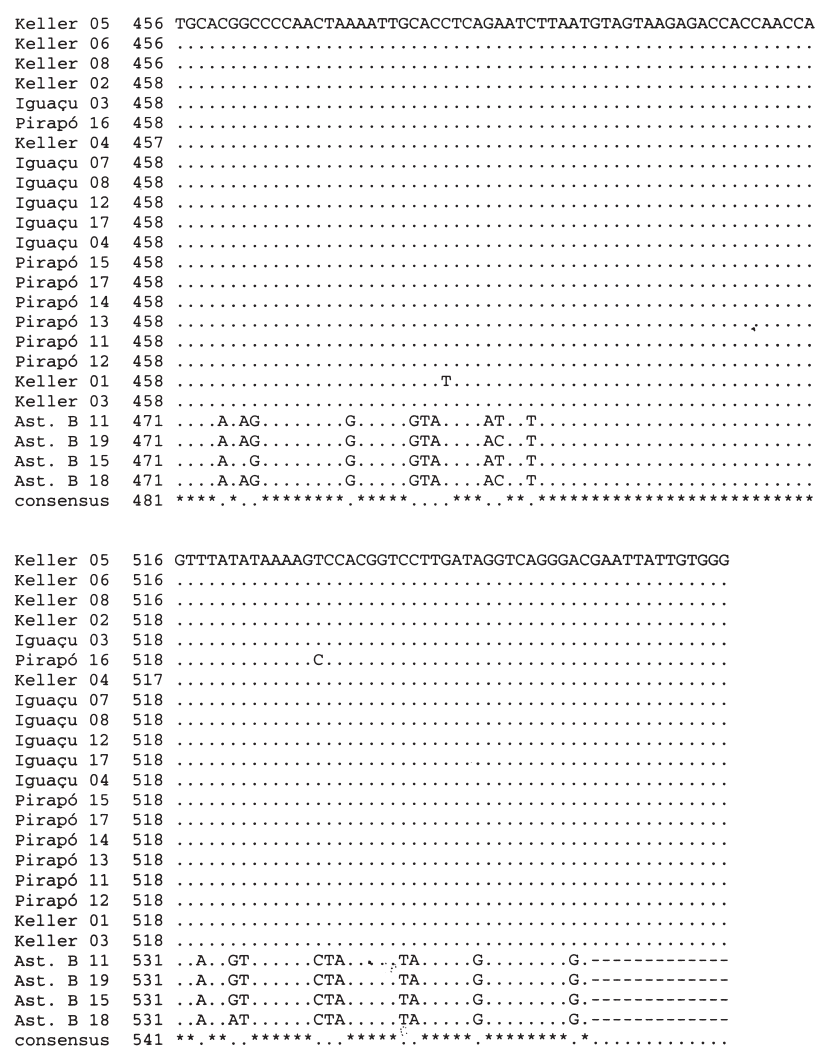

Figure 1 - (Cont.)
Table I - Genetic distances of Tamura and Nei (1993) based on mitocondrial control region sequences, with gamma distribution, among Astyanax altiparanae individuals from Iguaçu River and from the Keller and Pirapó tributaries of the Upper Paraná River basin, and Astyanax sp B individuals from the Iguaçu River.

\begin{tabular}{lcccc}
\hline & Keller & Pirapó & Iguaçu & A. sp B \\
\hline Keller & 0.000 & & & \\
Pirapó & 0.013 & 0.000 & & \\
Iguaçu & 0.017 & 0.019 & 0.000 & \\
A. sp B & 3.259 & 3.176 & 3.527 & 0.000 \\
\hline
\end{tabular}

population, as compared either to Keller or to Iguaçu. The molecular genetic evidence, in conjunction with morphological similarities (Graça and Pavanelli, 2002), demonstrated that the species status of Astyanax bimaculatus from the Iguaçu River should actually be stated as Astyanax altiparanae Garutti \& Britski, 2000. Furthermore, high genetic diversity within and high similarities between the populations, as indicated by of RAPD markers, suggested that this species was most probably introduced recently in the Iguaçu River basin, and that this introduction involved a large number of individuals.

Molecular tools associated to morphological analyses have been effectively applied in defining relationships of fishes in different levels, including among genus and species populations. The mitochondrial control region has been used extensively as a molecular marker because of its
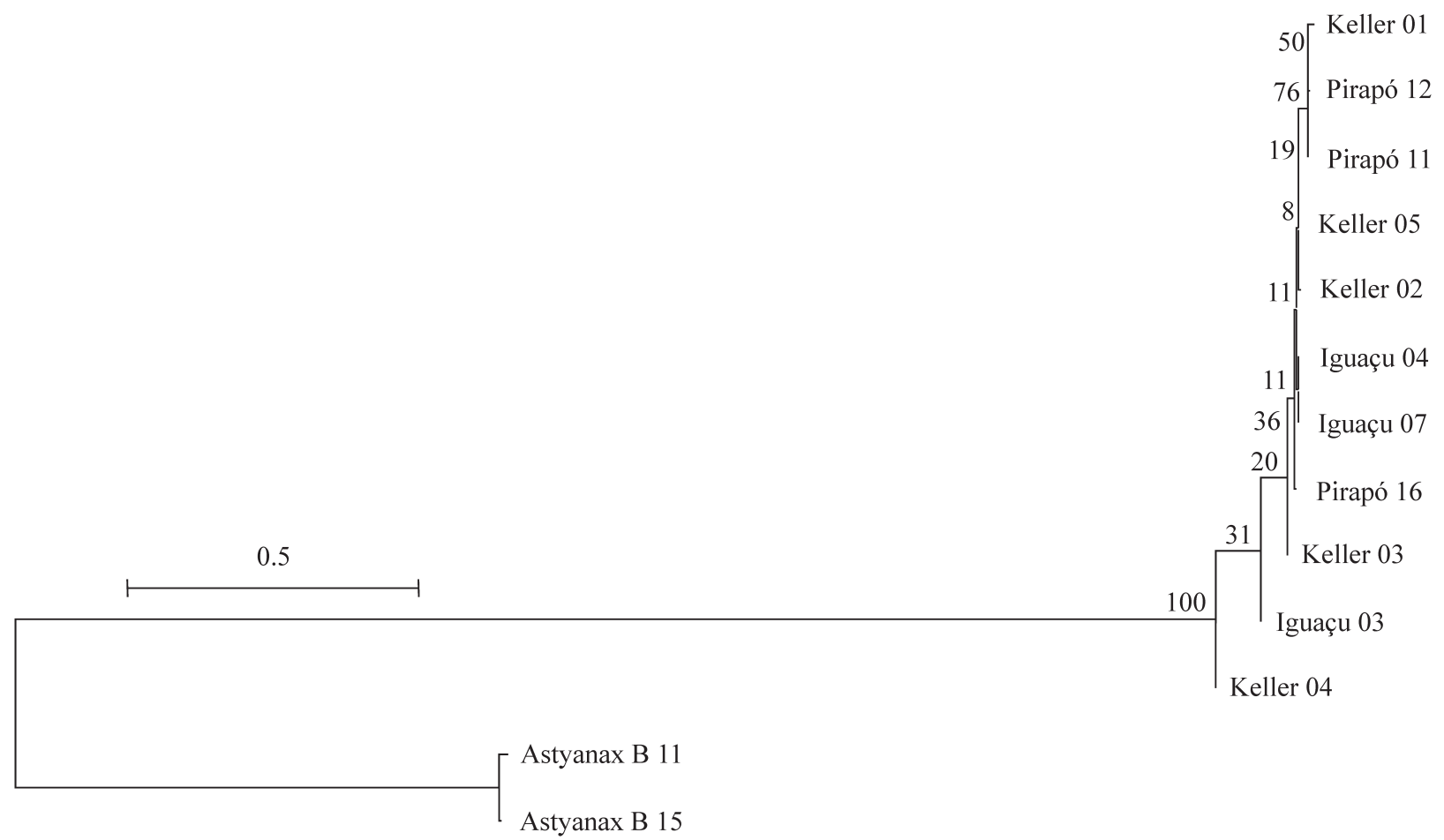

Figure 2 - Neighbor-joining tree for mitochondrial control region sequences of Astyanax altiparanae specimens from the Iguaçu River and from the Keller and Pirapó tributaries of the Upper Paraná River basin. Genetic distance was computed by using the Tamura and Nei (1993) method. The tree is rooted to the closely related species Astyanax sp B. Number on each node indicates bootstrap probability based on 1000 replications. 

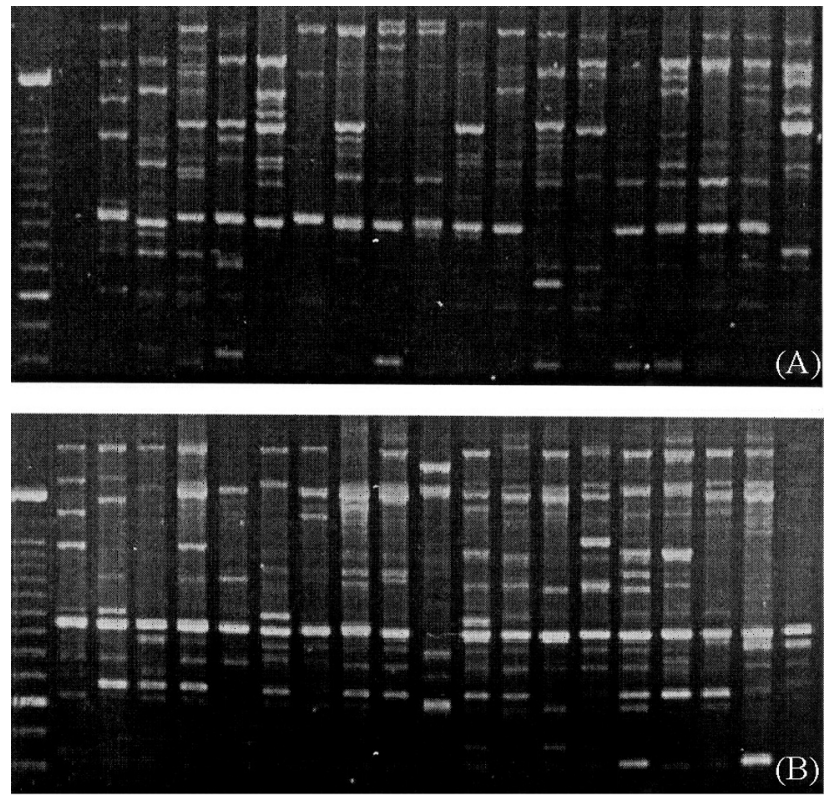

Figure 3 - RAPD profiles for Astyanax altiparanae using primer OPW09. (A) Individuals from the Keller River (lanes 3-11) and from the Pirapó River (Lanes 12-20), both from the Upper Paraná basin. Lane 2 is a negative control, without DNA. (B) Individuals from the Iguaçu River (Lanes 3-20). Lane 2 is a PCR replicate from Lane 3 of A. Lane 1 in A and B contains DNA molecular weight markers (Ladder 100 bp, Gibco BRL).

rapid rate of evolution compared to nuclear DNA and the significant literature available on the theory and application of mtDNA sequence analysis. In the present study, low genetic distances, according to Tamura and Nei (1993), were found among the Iguaçu, Keller, and Pirapó populations, as inferred from control region sequences (Table I; Figure 2). The high genetic similarity data estimated on the basis of the control region were reinforced by the cytochrome $b$ partial sequence and the complete sequences of tRNA ${ }^{\text {Pro }}$ and tRNA $^{\text {Thr }}$, which were identical among all Astyanax individuals, from both populations of the Upper Paraná basin and the population from the Iguaçu River. These results are consistent with findings in other vertebrate species, showing that although the mitochondrial protein encoding gene and the tRNAs do not evolve as rapidly as the control region, their nucleotide sequences are highly conserved at the intraspecific level, while they have been found polymorphic at the interspecific level (Meyer, 1994; Saccone et al., 2002). Furthermore, the genetic relatedness of all three Astyanax populations was obvious upon the contrast of their mtDNA sequences with those of the related species Astyanax sp B. As shown in Figure 2, individuals from the Iguaçu and Upper Paraná rivers were not discriminated by the neighbor-joining method, but they were clearly separated, with $100 \%$ bootstrap value, from Astyanax sp B. The genetic distances among specimens of all three studied Astyanax populations were in similar magnitudes to those observed among the individuals of the outgroup Astyanax sp B (Figure 1). The molecular genetic relatedness inferred from mtDNA sequences indicated that the studied Astyanax population sampled in the Iguaçu River should be joined together with the Keller and Pirapó populations, within the Astyanax altiparanae species.

RAPD markers corroborated the inference of high genetic similarity among the three Astyanax populations, as estimated from mtDNA sequences, and they indicated high nuclear genetic diversity within each population. The Shannon indexes based on RAPD markers revealed high genetic diversity within the Iguaçu population, at very similar levels to those of the Keller and Pirapó populations. This result indicated that the genetic variability was not lost during the establishment of these three populations. The highest Nei's unbiased genetic distance, estimated as 0.070 from RAPD markers (Table III), is considered low and consistent with intraspecific distances. Nei's genetic distances between species from the same genus have been found no lower than 0.162 and over 0.3 in most species, as estimated from enzyme studies (Thorpe and Solé-Cava, 1994). Analyses of

Table II - Approximate size, in number of base pairs (bp), of DNA fragments of polymorphic loci of Astyanax altiparanae from the Keller and Pirapó tributaries of the Upper Paraná River basin, and from the Iguaçu River, amplified by PCR with ten RAPD primers.

\begin{tabular}{|c|c|c|c|c|c|c|c|c|c|c|}
\hline \multirow[t]{2}{*}{ Primers } & \multicolumn{10}{|c|}{ Bands ( pb) } \\
\hline & $\mathrm{a}$ & $\mathrm{b}$ & $\mathrm{c}$ & $\mathrm{d}$ & $\mathrm{e}$ & $\mathrm{f}$ & $\mathrm{g}$ & $\mathrm{h}$ & $\mathrm{i}$ & $\mathrm{j}$ \\
\hline OPX05 & 1700 & 1600 & 1200 & 900 & 700 & 650 & 500 & & & \\
\hline OPX06 & 2400 & 2200 & 1600 & 1350 & 1200 & 1150 & 950 & 900 & 750 & 400 \\
\hline OPX07 & 1800 & 1600 & 1350 & 1300 & 1000 & 850 & 800 & 450 & & \\
\hline OPX08 & 2000 & 1900 & 1600 & 1500 & 1300 & 1150 & 1000 & 700 & & \\
\hline OPX19 & 1700 & 1500 & 1250 & 1000 & 900 & 750 & & & & \\
\hline OPW03 & 2200 & 2000 & 1500 & 1300 & 950 & & & & & \\
\hline OPW04 & 2800 & 2600 & 1900 & 1700 & 1500 & 1400 & 500 & & & \\
\hline OPW09 & 3000 & 2200 & 2000 & 1500 & 1200 & 950 & 650 & 400 & & \\
\hline OPW17 & 2300 & 2100 & 1700 & 1450 & 1200 & 1100 & 900 & 700 & 650 & 600 \\
\hline OPW19 & 1600 & 1500 & 1300 & 1000 & 900 & 850 & 750 & 700 & 650 & 600 \\
\hline
\end{tabular}


Table III - Unbiased Nei's distances among three Astyanax altiparanae populations from the Keller and Pirapó tributaries of the Upper Paraná River basin and from the Iguaçu River, based on RAPD markers.

\begin{tabular}{lccc}
\hline & Keller & Pirapó & Iguaçu \\
\hline Keller & 0.000 & & \\
Pirapó & 0.070 & 0.000 & \\
Iguaçu & 0.050 & 0.059 & 0.000 \\
\hline
\end{tabular}

Table IV - Matrix of fixation indexes $F_{\text {st }}$ (lower-left) and of number of migrants per generation $\mathrm{Nm}$ (upper-right) among three populations of Astyanax altiparanae from the Keller, Pirapó and Iguaçu rivers, based on RAPD markers.

\begin{tabular}{lllc}
\hline & Keller & Pirapó & Iguaçu \\
\hline Keller & 0.0 & 2.4 & 4.0 \\
Pirapó & $0.093^{*}$ & 0.0 & 2.9 \\
Iguaçu & $0.059^{\text {n.s. }}$ & $0.078^{*}$ & 0.0 \\
\hline
\end{tabular}

*Significant at the $5 \%$ probability level by the $\chi^{2}$ test.

n.s. Non-significant at the $5 \%$ level of probability by the $\chi^{2}$ test.

RAPD markers of fish species from the floodplain of the Upper Paraná River basin revealed relatively high Nei's unbiased genetic distances, as 0.504 between Pseudoplatystoma corruscans ('pintado') and Pseudoplatystoma fasciatum ('cachara'), and 0.729 between Steindachnerina brevipinna and Steindachnerina insculpta (Sekine et al., 2000; Oliveira et al., 2002). Even though the studied species within each of these two genus are so closely related that they crossbreed generating hybrids, their genetic distances were obviously much higher than those among the three Astyanax populations. Therefore, the low genetic distances among the two Astyanax altiparanae populations from the Upper Paraná river basin and the studied Astyanax population from Iguaçu river are coherent with expected intraspecific distances. Nei's unbiased genetic distances are considered suitable for long evolutionary processes, with populational divergences due to genetic drift and mutational events (Weir, 1990), and its value is proportional to the time of divergence and the rate of gene substitution per locus and per generation. Nei's unbiased estimates of low genetic distances based on RAPD did not discriminate the Astyanax populations from the Iguaçu and Upper Paraná river basins, indicating that they maintain the genetic identity of a single recent common ancestor. Intraspecific differentiation was significant only at $5 \%$ level for the Pirapó population as compared to both the Iguaçu and Keller populations, by the fixation index $F_{S T}$. This result seems to indicate an expected level of intraspecific variation. RAPD estimates of gene flow on all loci among all populations was high, ranging from 2.4 to 4.0 migrants per generation (Table IV), indicating that the all three populations are very similar, and did not differentiate, not even by genetic drift.

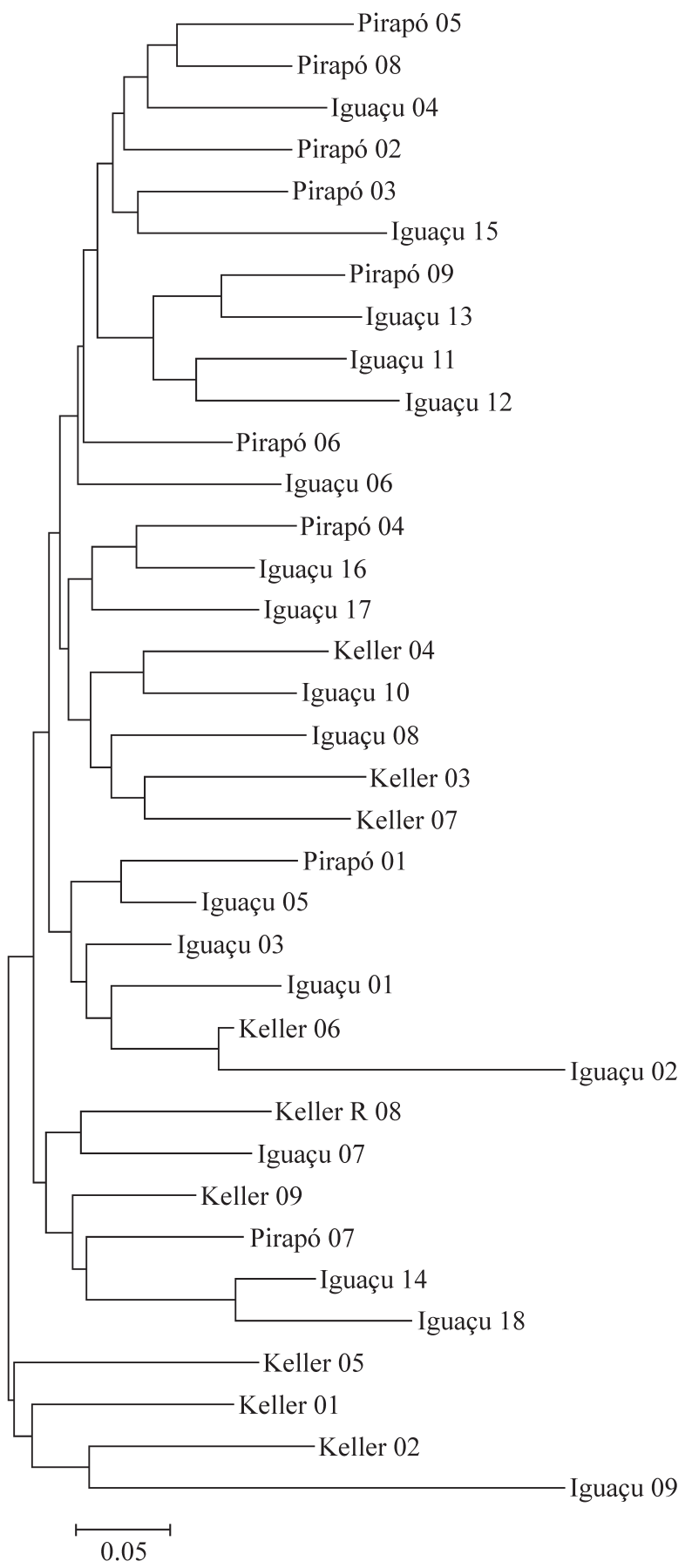

Figure 4 - Neighbor-joining tree, based on the matrix of the arithmetic complement of the similarity coefficient of Nei and Li (1979), obtained from RAPD markers of Astyanax altiparanae individuals from the Iguaçu River, and from the Keller and Pirapó tributaries of the Upper Paraná River basin.

The Iguaçu Falls have been considered the principal factor for fish isolation and speciation in the Iguaçu River basin, as initially suggested by Haseman (1911). In fact, most fish species from the Iguaçu River basin have been characterized as endemic, including species of the genus Astyanax (Sampaio, 1988; Severi and Cordeiro, 1994; Ga- 
ravello et al., 1997). Nevertheless, introduced species, admittedly not very abundant, have also been reported in this hydrographic basin (Agostinho and Gomes, 1997). The high genetic similarity and high gene flow estimated among A. altiparanae populations from tributaries of the Upper Paraná River basin and from the Iguaçu population, as well as the high genetic diversity within each population, at very similar levels in the two hydrographic basins, demonstrated that the Astyanax altiparanae population from the Iguaçu River is not endemic. Such high genetic similarity agrees with the hypothesis of introduction of this species in the Iguaçu River from the Upper Paraná River basin (Garavello et al., 1997). Furthermore, the molecular data in the present work suggest a recent separation of the Iguaçu and Upper Paraná populations, maintaning the intrapopulational genetic diversity representative of the ancestral population. In addition, the time or number of generations would not be yet sufficient for mutation accumulation of mutations, as detected by the methodology used. Another possible hypothesis to explain these results, apparently less likely, would be an old introduction of A. altiparanae from the Upper Paraná River basin into the Iguaçu River, followed by recurrent migration or transposition of a high number of individuals, to such a degree that the genetic differentiation would be mitigated or eliminated.

\section{Acknowledgments}

The authors gratefully acknowledge Wilson M. Furuya for helping with fish sampling, Weferson J. Graça for assisting with morphological comparisons of studied populations, Reimar Padovani for helping in DNA sequencing, and COPEL and NUPELIA-UEM for logistic support. Part of this research was supported by grants from $\mathrm{CNPq}$, CAPES, and COPEL.

\section{References}

Agostinho AA and Gomes LC (1997) Manejo e monitoramento de recursos pesqueiros: perspectivas para o reservatório de Segredo In: Agostinho AA and Gomes LC (eds) Reservatório de Segredo: Bases Ecológicas para o Manejo. Eduem, Universidade Estadual de Maringá, PR, Brazil, pp 319-364.

Almeida FS, Pelegrinelli MH and Sodré LMK (2001) RAPD and isoenzyme analysis of genetic variability in three allied species of catfish (Siluriformes: Pimelodidae) from the Tibagi River, Brazil. J Zool Lond 253:113-120.

Altschul SF, Madden TL, Schäffer AA, Zhang J, Zhang Z, Miller W and Lipman DJ (1997) Gapped BLAST and PSI-BLAST: a new generation of protein database search programs. Nucleic Acids Res 25:3389-3402.

Black, B (1997) RAPDFST 401 - A FORTRAN Program to estimate $\mathrm{F}(\mathrm{ST})$ and effective migration rates among subpopulations using RAPD-PCR files. Colorado State University.

Black B and Antolin M (1997) Explanation of RAPDDIST 10. Colorado State University.

Faber JE and Stepien CA (1977) The utility of mitochondrial DNA control region sequences for analyzing phylogenetic relationships among populatios, species, and genera of the Percidae In: Kocher TD and Stepien (eds) Molecular Systematics of Fishes. Academic Press, New York, pp 129-143.

Garavello JC, Pavanelli CS and Suzuki HI (1997) Caracterização da ictiofauna do rio Iguaçu In: Agostinho AA and Gomes, LC (eds) Reservatório de Segredo: Bases Ecológicas para o Manejo. Eduem Universidade Estadual de Maringá, pp 61-84.

Garutti V and Britski HA (2000) Descrição de uma espécie nova de Astyanax (Teleostei: Characidae) da bacia do alto Rio Paraná e considerações gerais sobre as demais espécies do gênero na bacia. Comum Mus Ciênc Tecnol PUCRS Sér Zool 13:65-88.

Graça WJ and Pavanelli CS (2002) Comments on the geographic distribution of Astyanax altiparanae Garutti \& Britski, 2000 (Pisces, Characiformes) in the Rio Iguaçu basin. Acta Scientarium 24(2):(In Press).

Haseman, JD (1911) Some new species of fishes from the rio Iguaçu. Ann Carnegie Mus 7:374-387.

Irwin DM, Kocher TD and Wilson AC (1991) Evolution of cytochrome b of mammals. J Mol Evol 32:128-144.

Kocher TD and White TJ (1989) Evolutionary analysis via PCR. In: Erlich HA (ed) PCR Technology: Principles and Applications for DNA Amplification. Stockton Press. New York. pp 137-147.

Kumar S, Tamura K, Jakobsen IB and Nei M (2001) MEGA2: Molecular Evolutionary Genetics Analysis software. Bioinformatics. Arizona State University, Tempe, Arizona, USA.

Lowe TM and Eddy SR (1997) tRNAscan-SE: A program for improved detection of transfer RNA genes in genomic sequence. Nucleic Acids Res. 25:995-964.

Lynch M and Milligan BG (1994) Analysis of population structure with RAPD markers. Mol Ecol 3:91-99.

Meyer A (1994) DNA technology and phylogeny of fish In: Beaumont AR (ed) Genetics and Evolution of Aquatic Organisms. Chapman \& Hall, London, pp 219-249.

Meyer A, Kocher TD, Basasibwaki P et al. (1990) Monophyletic origin of Victoria cichlid fish suggested by mitochondrial DNA sequences. Nature 347:550-553.

Nei M (1978) Estimation of average heterozygosity and genetic distance from a small number of individuals. Genetics 89:583-590.

Nei M and Li W-H (1979) Mathematical model for studying genetic variation in terms of restriction endonucleases. Proc Natl Acad Sci USA 76:5269-5273.

Oliveira AV, Prioli AJ, Prioli SMAP, Pavanelli CS, Julio Jr HF and Panarari RS (2002) Diversity and genetic distance in populations of Steindachnerina in the Upper Paraná river floodplain. Genetica (in press).

Saccone C, Gissi C, Reyes A, Larizza A, Sbisà E and Pesole G (2002) Mitochondrial DNA in Metazoa: degree of freedom in a frozen event. Gene 286:3-12.

Saitou N and Nei M (1987) The Neighbor-joining method: a new method for reconstructing phylogenetic trees. Mol Biol Evol 4:406-425.

Sampaio FAA (1988) Estudos taxonômicos preliminares dos ChaNeighbor-joining tree, based on the matrix of the arithmetic complement of the similarity coefficient of Nei and Li (1979), obtained from RAPD markers of Astyanax altiparanae individuals from the Iguaçu River, and from the Keller and Pirapó tributaries of the Upper Paraná River ba- 
sin.raciformes (Teleostei, Ostariophysi) da bacia do rio Iguaçu, com comentários sobre o endemismo dessa fauna. MSc Thesis, Universidade Federal de São Carlos, São Carlos.

Sekine ES, Prioli AJ, Julio Jr HF, Prioli SMAP and Castro LL (2000) Análise da divergência genética entre populações de Pseudoplatystoma fasciatum e Pseudoplatystoma corruscans (Pisces-Siluriformes) utilizando marcadores RAPD. Genet Mol Biol (Suppl) 23(3):101

Severi W and Cordeiro AAM (1994) Catálogo de Peixes da Bacia do Rio Iguaçu. IAP/GTZ, Curitiba, 112 pp.

Sivasundar A, Bermingham E and Orti G (2001) Population structure and biogeography of migratory freshwater fishes (Prochilodus: Characiformes) in major South American rivers. Mol Ecol 10(2):407-417.

Stepien CA and Kocher TD (1997) Molecules and morphology in studies of fish evolution In: Kocher TD and Stepien (eds) Molecular Systematics of Fishes. Academic Press, New York, pp 1-11.
Swofford DL (2002) PAUP*: Phylogenetic Analysis using Parsimony (*and other methods), vers 4. Software, Sinauer Associates, Sunderland.

Tamura K and Nei M (1993) Estimation of the number of nucleotide substitutions in the control region of mitochondrial DNA in humans and chimpanzees. Mol Biol Evol 10:512526.

Thorpe JP and Solé-Cava AM (1994) The use of allozyme electrophoresis in invertebrate systematics. Zool Scr 23:3-18.

Weir BS (1990) Genetic Data Analysis. Sinauer Associates Inc., Sunderland, $376 \mathrm{pp}$.

Whitmore DH, Thai TH and Craft CM (1992) Gene amplification permits minimally invasive analysis of fish mitochondrial DNA. Trans Am Fish Soc 121:170-177.

Williams JGK, Kubelik AR, Livak KJ, Rafalski JA and Tingey SV (1990) DNA polymorphisms amplified by arbitrary primers are useful as genetic markers. Nucl Acids Res 18:6531-6535.

Yeh FC, Boyle T, Ye Z and Xiyan JM (1999) POPGENE Version 131: Microsoft Window-based freeware for population genetic analysis. University of Alberta and Center for International Forestry Research. 